\title{
Place Attachment Dimensions and Role Assessment in Modern Hospitals
}

\author{
Mohammadreza Rohani ${ }^{1} \&$ Vahid Shaliamini ${ }^{2}$ \\ ${ }^{1}$ Master of Architecture, Islamic Azad University, North Tehran Branch, Iran \\ ${ }^{2}$ Architecture PhD, University Instructor, Islamic Azad University, Central Tehran Branch, Iran \\ Correspondence: Mohammadreza Rohani, Islamic Azad University, North Tehran Branch, Iran. Tel: \\ 98-2297-7863. E-mail: mohamadreza.ac@gmail.com
}

Received: January 1, 2015

Accepted: January 12, 2015

Online Published: October 31, 2015

doi:10.5539/mas.v9n12p183

URL: http://dx.doi.org/10.5539/mas.v9n12p183

\begin{abstract}
Hospitals play a significant role in people's physical and psychological health, as well as medical and ducational researches of the experts. Therefore, hospitals' importance is due to both health-care services and the educational effect. Many hospitals do not meet international standards due to oldness and inattention to space users. Based on the studies on place attachment, dimension, and effects, the paper attempts to promote place attachment in clinical spaces through creative exploration. Qualities such as place identity, emotional attachment, place dependence, social bonding, spatial behavior, and functional attachment are the research analysis criteria. The research methods is practical and descriptive-analytic evaluating the problem's invisible horizons through a critical, objective, and concrete viewpoint and makes creative strategies and models possible which are responsive to different environmental dimensions especially human dimension. To study the criteria for valuation and space creation, the users and what they admire, associate, understand, and use and for which they have "sense of belonging" were also considered. The research results reveal that designing a modern hospital based on the promotion of place attachment results in the quick recovery of the patients, hospital staff's job satisfaction, medical education improvement and also solutions to the enhancement of the environment quality of the hospital.
\end{abstract}

Keywords: hospital, place attachment, place identity, emotional attachment, community attachment, functional attachment, spatial behavior

\section{Introduction}

Hospital is a social entity which has emerged gradually for human health and survival and disease treatment and is now a necessity in human societies owing to developments in science, techniques, skills, and life styles. The growth of environmental psychology and theories such as personal space, territory reliability, aggregation, place meaning, identity, led to the study of the environmental impact on human. Place attachment is the intersection of the physical elements of mental concepts and activities about the place. This attachment sense changes the space to a place with special sensory and behavioral characteristics. Bonaiuto, an environment psychologist, has studied the emotional interaction between the individual and the place called "place attachment" which promotes satisfaction of the workplace and treatment place, sense of belonging, safety, identity and environmental perception (Bonaiuto, M, etal ,1999, p,19). Place attachment is important because it has a significant role in making and enhancing the responsibility, cooperation, and self-assistance in hospitals and provides a more efficient way to resolve the problems and improve the disease, job, and educational conditions. Today, hospitals, constructed obstinately, are boring, inhuman, and unsafe, with low quality, and inconsistent and meaningless relationships. In many cases, the correct values and relationships are disturbed due to the changes in physical environment, use and activities, especially for those who have a long-term place dependency. In regards with the afore-mentioned points, the research main question can be stated as: "How strong is the attachment of the patients, personnel, medical and educational staff to the hospital at which they are to be treated, work, and educate and what are the factors affecting it?" Accordingly, the subject and the theoretical principles are defined and then a place-attachment-based approach is presented.

\section{The Origin of Place Attachment Concept}


Emotions have been recognized as fundamental parts of the human-environment interaction but there is, however, a paucity of knowledge regarding the impact that feelings of attachment towards a place (hospital) have on the well-being of people with mental illness (Kaplan, S, \& Kaplan, R. 1984),( Morgan, P,p, 30). Place attachment is a multifaceted phenomenon that occurs over time and integrates different aspects of human-environment interaction (Rollero, C., \& De Piccoli, N. 2010,p 60). It has been defined as an emotional bond established between a person and a place in which a particular place acquires a special meaning for the individual and is associated with feelings of security, control and opportunities for privacy and restoration (Harris, P. B., Werner, C. M., Brown, B. B., \& Ingebritsen, D. 1995,p,15),( Hidalgo, M. C., \& Hern_andez, B. 2001,p,21) Different levels of place attachment can be experienced by the individual. These levels may vary from a sense of belonging to a place, to feelings of identification with it, and at the highest level to a feeling of commitment and willingness to sacrifice for the sake of the place (Hern_andez, B., Hidalgo, M. C., Salazar-Laplace, E., \& Hess, S 2007,p,27),( Kaltenborn, B. P. 1998,p,18),( Shamai, S. 1991,p,22),( Twigger-Ross, C., Bonaiuto, M., \& Breakwell, G. 2003) Some studies have reported a connection between place attachment and health outcomes (Brown, B., \& Perkins, D. 1992), ( Harris, P. B., Werner, C. M., Brown, B. B., \& Ingebritsen, D. 1995,p, 15). Attachment and satisfaction with the place of residence have been also acknowledged as predictors of mental health outcomes in vulnerable groups such as, elderly people and people with psychiatric disabilities (Evans, G.W., Kantrowitz, E., \& Eshelman, P. 2002,p, 57),( Wright, P. A., \& Kloos, B. 2007,p,27) It has been claimed that there is a need for theoretical development regarding which physical dimensions contribute to the growth of meaning and attachment towards different environments, and future research directions that emphasize the physical aspects of place attachment have been recommended (Lewicka, M. 2011,p,31), (Stedman, R. C. 2003,p,16). The information gathered by the concept of sense of place implies an assessment of the setting that results from a conscious effort to evaluate its actual quality rather than from familiarity through long residence (Easthope, H. 2004,p,21). From the environmental psychology literature suggestions have been made regarding the link between residential rootedness and place attachment and identity. The concept of 'rootedness' has been differently defined across the literature, shifting from concepts of unselfconscious association with a place (Proshansky, H. M., Fabian, A. K., \& Kaminoff, R. 1983,p,3) to an overarching indicator of the quality of the attachment established between a person and a place (Hummon, D. 1992,p,253),( Tuan, Yi-Fu ,1980,p, 24). This latter definition goes beyond the simple familiarity with the setting since it claims that the quality of the experience established in the setting matters more than duration (Tuan, Yi-Fu ,1977). Moreover, it includes a self- conscious decision to live in a place and to take active interest in it, 'ideologial rootedness' (Hummon, D. 1992,p,253), (Lewicka, M. ,2011,p,43) In general, place attachment is a subject people face daily which is based on past experiences, behavioral, cognitive, sensory, and social structures (Daneshpour, S, 2011,p, 40). Further, attachment sometimes emerges from behavioral and social structures such as socialization and gets activated by safety threat (Goldberg, S, 2000, ,p, 85). which is the base of many researches on place attachment. "Place attachment" term refers to a place emotional impact which attracts people culturally and sensorially. The sensory, emotional and inner impact of a place on people is the center of place attachment thinking since people can be attracted to an abject, house, building, neighborhood or a natural setting. In fact, place attachment is a symbolic relationship with a place which shapes through the common emotional and sensory meaning that people give to a special place or land and is the basis of people's perception of a place and how of relationship with it (Low, S.M., and Altman, I., 1992, p, 12). Place attachment is a dimension of sense of place and positive emotional dependency which develops between an individual and a place (Stedman, R.C., 2003,p, 682). The term expresses an individual's feeling towards a geographical location which bonds a person to a place sensorially. In fact, a positive experience of a place results from positive beliefs and feelings that an individual creates through interaction with a place (Rubinstein, R.L and Parmelee, P.A., 1992,p, 139). According to the definitions, place attachment is the emotional relationship between the place and the individual. While the term refers to a mental concept and an inner and sensory relationship, different studies are conducted to assess the amount of people's attachment to different places in order to quantify the concept. The research achievement which relies on the individual's place attachment process and its amount reveals that place attachment is of various dimensions that means people have pointed to different dimensions in order to define the feeling of place attachment and its reason (Daneshpour, S, 2011,p, 40).

\section{Literature Survey}

Generally, to explain place attachment dimensions, following parameters can be described:

\subsection{Functional Attachment}

Different studies are conducted on the place attachment emphasizing the role of place function and framework (Eisenhauer, B.W., Krannich, R.S. and Blahna, D.J. 2000,p,13). They attempt to find the answer to the question: 
"What places are important to people and why?" The results show that the physical, functional and social properties of a place all have an identical role in place attachment. Stedman's studies on the role of physical-functional dimension of place attachment display its direct role in satisfaction and the indirect role in place attachment affected by the place symbolic meanings (Stedman, R.C., 2003,p, 682). The studies refer to context, availability of services and facilities, place location, relationship with surroundings, and many others (Bonaiuto, M., Fornara, F. and Bonnes, M. 2002,p, 988). This dimension describes meeting individual's targets and the needs based on the place quality at meeting the user's needs in comparison with others similar places which depends on the individual's past experiences, place access, and the activity modes (Vaske, J.J., and Kobrin, K.C. 2001,p, 18). The dimension can be described by following statements: I have fast and suitable access to different parts at my workplace, I have a good feeling about diversity of pleasing colors at my workplace, I enjoy appropriate light at my workplace, there is suitable green space and natural environment at my workplace, my workplace building has an appropriate shape and space, my workplace space is comfortable, my workplace enjoys a suitable protection against different outside factors, I enjoy open spaces at my workplace.

\subsection{Emotional Attachment}

This dimension associates with the individual-place sensory interaction and the role in the individual identity and describes dimensions which explain the individual identity in relationship with the physical place (Williams, D.R., and Roggenbuck, J.W. 1989,p,32). It motivates people's presence to pass the time (Proshansky, H.M. 1978,p,155) relying on the individual sensory ties with a particular place (existence of special elements in a place or its history) and is shaped by frequent attendance (Warzecha, C. A., and Lime, D.W. 2001,p,32). It creates sense of belonging, gives meaning to the individual life, causes responsive and committed behaviors to place, and can promote environmental behaviors. It can be described by the following statements: I feel safe after entering my workplace, I have no tendency to change my workplace because I'm used to it, I feel my workplace is part of me, this place is important to me and gives me credit, I am happy about living and working at my workplace, I like my workplace better than other health-care centers, I tell others that I work in this place and I feel proud of it, if I move to an unfamiliar hospital, I would feel distressed, I am dependent on the hospital where I work.

\subsection{Place Dependency}

Place dependency defined by three dimension; 1- A place responsiveness to the individual needs, or in other words, the opportunities a place provides to meet needs and achieve goals (Stokols, D., and Shumaker, S.A., 1981,p,41) describes the possibility of participation in special activities in a place (Bricker, K.S. and Kerstetter, D.L. 2000,p, 22) 2- Sensory impression in relation with a place: positive or negative feeling for a place (Rosenberg, M.J., and Hovland, C.I., 1960,p,14) 3- The individual's past place experiences based on the number of past experiences of similar places, Number of attendance in a particular place, Duration of stay in a place. In fact, place dependency is the functional element of place attachment which reflects the individual's relationship with the place and makes a continuous relationship between the individual and a special place based on the responsiveness to their activities and goals (Stokols, D., and Shumaker, S.A., 1981,p,41). It is also dependent on the demographic characteristics, attendance motivations, place perception, assessment of place management and type of activities (Daneshpour, S, 2011,p, 40). It is described by the following statements: It is the best place for doing my favorite activities, the activities I do are more important than other activities, I do not replace another place for doing those activities, I enjoy this place better than other places, I feel better in similar places, I try to use my workplace hospital to treat my diseases and those of my family, I introduce this hospital to others, I greet and socialize with my workplace colleagues.

\subsection{Place Identity}

Proshansky was the first who studied identity through his article "The City and Self Identity". He believes that the place identity can be assessed by the statement "This place shows that I exist". Place identity is a dimension of self which describes an individual's identity in regards with the (physical) place based on beliefs, preferences, feelings, values, goals, behavioral tendencies and skills consciously and unconsciously while place identity depends on the individual special experiences and socialization, it reflects people and groups living in that particular place (Proshansky, H.M. 1978,p,155). In fact, place identity is what people make in their mind about a particular place (i.e., the place image). Place identity is the mental image, experiences, thoughts, memories, direct feelings, and targeted interpretation of what it is and what it should be (Williams, D.R., and Vaske, J.J., $2003, p, 49)$. What is unique about a place (i.e., the spirit of a place) is made within the identity which can stay stable despite the change(s) in elements and has the following levels: Individual level: which is different among different people; Group or social level: which is a symbol of signs, common meanings, and social interactions 
within groups and communities; Public level: expectations and perceptions of the public dictated by media,government and other entities that are superficial and based on common meanings and symbols. The center of this quality is a factor called "the individual place past" by Proshansky which includes the place type and features and is regarded as a tool to meet the cultural-social, psychological and physiologic needs. He classifies the place identity dimensions into the following:

1. Descriptive-Cognitive dimension: It relates to the individual's imaginations, memories, thoughts, and the conscious and unconscious beliefs about the physical features of a place.

2. Evaluative-Emotional dimension: It relates to the individual's feelings and preferences in terms of a place context such as color, style, form, sounds, dimensions, lighting, and the like. The combination of the place elements with the real world experienced by people and groups is the other aspect of this dimension. Even though some dimensions are unique for each individual, sometimes different groups have common viewpoints. It is described by terms such as: my favorite room, city and the like which are conscious or unconscious expression of this dimension.

3. The individual's needs of a place: It relates to the individual's role and expectations, beliefs, feelings, ideas, and induction and it is usually understood best when the place and the individual's expectations and needs do not agree (Proshansky, H.M., Fabian, A.K. and Kaminoff, R., 1983,p,3). Stimulation of place identity in an individual is connected to different factors such as frequent experience of the place, attendance duration, frequency of interaction with the place (functional dependency on place), place preference, and attention (Kyle, G.T., Absher, J.D. and Graefe, A.R. 2003,p,25). On the other hand, social factors and people's attendance also affect the place identity. In other words, people develop it through the enhancement of the social sense of belonging (Williams, D.R., and Roggenbuck, J.W. 1989,p, 32). This dimension is described by the following statements: This place is a reflection of my personality, visiting the place tells me who I am (Kyle, G., Graefe, A., Manning, R. and Bacon, J., 2004,p, 24), this place has different meanings, working in this place gives me identity, I feel more comfortable in this place comparing with other places, I feel distressed if my workplace damages.

\subsection{Community Attachment}

Environmental psychology deals with both physical and community dimensions of a place (Scherl, L.M., 1989,p, 11). The positive relationship between an individual and the physical place and the spiritual satisfaction are connected with social connections in a place (Chavis, D.M. and Pretty, G, 1999,p, 27) so that business and social interactions in a place give meaning to it. Accordingly, two factors are important: 1- Place identity which depends on region, common memories and time and place dependency that are one dimension of place experience (Chawla, L, 1992,p, 63) 2- The importance of community connections in a place should not be neglected (Daneshpour, S, 2011,p, 45). Place attachment develops through the individual's positive interaction and their social conformity and the place attachment intensity is directly related to the amount and intensity of this relationship (Mesch, G.S. and Manor, O. 1998,p,30). Hence, place attachment is described by three in a place, participation in group activities and events. In general, people develop place attachment based on individuals' attachment (Daneshpour, S, 2011, p, 42). Therefore, the individual's attendance in a place with others is a strong factor for people to decide on if to stay in a place. In this line, people may look for places in which there are people with similar characteristics such as class, ethnicity, religion, economic group, life style, education, income, children's upbringing method, and race. Despite the fact that the individuals' homogeneity encourages meetings, increases interaction with physical and social places, and promotes place attachment, non-homogeneous social places are also an opportunity for people to be with each other and experience free and rich interactions (Daneshpour, S, 2011, p, 42). A favorite social space increases people's satisfaction and encourages informal communications and participation in social activities and enhances place attachment (Daneshpour, S, 2011,p, 43). In many cases, the desired place attachment is justified by the place' social factors in undesirable physical conditions (Bonaiuto, M., Fornara, F. and Bonnes, M. 2002,p, 988). The dimension can be described by the following statements: Interaction and acquaintance with my workplace colleagues and the hospital staff give me personality, working in this place reminds me of past memories, I feel I have many commonalities with others by working at this place, I build up self-confidence through communication and interaction with the acquaintances at my work place.

\subsection{Cultural Dimension}

Groups, families, community members and similar cultures have a similar sense of place attachment to a particular place (Daneshpour, S, 2011,p, 40). On the other hand, place attachment depends on activities people do proportionate to their culture (Low, S.M., and Altman, I., 1992,p,12). Generally, cultures also affect the 
groups' interaction with a place due to their role in shaping place performances.

\subsection{Individual Spatial Behavior}

Connection between an individual's behavior and architecture that appears through mental images shape our spatial behavior including historic and collective space (Van schalk, L, 2008, p, 9). Regarding spatial behavior, Van schalk states that "Would we be content to inhabit the horizontal slabs of space pressed between the minimum ceiling heights specified by building codes that are layered through our cities ubiquitously from cape to cairo?" He also states that "We are unaware of the fact that we are prisoners of our mental space" (Figure 1) (Van schalk, L, 2008, p, 9).

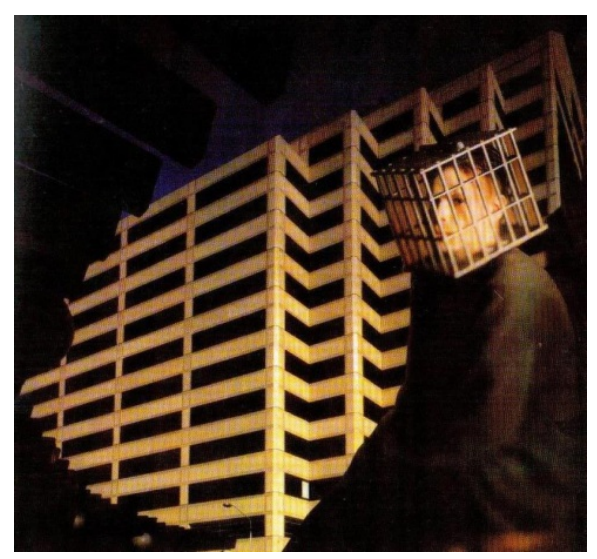

Figure 1. Mental Space, by Peter Lyssiotis, RMIT University, 1998

Place attachment varies from individual to individual, People select the places and get attached to them based on conscious preferences stemming from individual features. Dovey notes that places reflect the identities. Differences and competition in different groups based on gender, class, religion, ethnicity, and culture and display the individual's political orientations; power, freedom, interests, social system, and common interests in use motivation (Daneshpour, S, 2011, p, 40). To describe the properties of the individual spatial behavior and the role in interaction with place, different factors such as age, gender, income, marital status, education, social class, and job are mentioned (Low, S.M. and McDonogh, G.W, 2001, p,103).

\subsection{Time, Memories, and Experiences}

Place attachment develops when people have long-term or strong experiences of a place. It is through this process that a place finds meaning and rootedness which means merging of the individual and the place happens (Daneshpour, S, 2011,p, 40). As stated earlier, time or duration of settlement and familiarity with a place helps place attachment intensify which is studied and confirmed by many researchers (Pretty, G, Chipuer, H.M, Bramston, P, 2003,p, 23). Time highly affects the amount of place attachment in adults and children which can be studied both in the process and amount of place attachment (Daneshpour, S, 2011,p, 40). The individual interactional past is concealed in past memories and experiences and also their future expectations of a particular place that helps place attachment intensity. It should be noted that dif

ferent places have different potentialities in interaction with individuals (Milligan, M.J.,1998,p, 21). The individual's past interactions with a special place and the relationship intensity, or in other words, place attachment, also depends on the experience meaningfulness. That is to say, the more important the experience or its perception, the stronger the place attachment would be.

\section{Discussion}

The Place Attachment Factors Affecting the Patients' Treatment and Job Satisfaction and ducational Improvement in Hospitals

\subsection{Role of Modern Technologies and Hospital Information System (HIS)}

Existence of infrastructures for receipt and transfer of the patients' information is very important to treatment acceleration. Hospitals should move in line with the latest medical, engineering, and environmental technologies in order to enhance optimum consumption of energy, save the time, cost and human force, shorten the treatment period, and achieve more exact results medically and educationally which end up in place attachment. According 
to Hebda, hospital information system is comprised of clinical information system and management information system. The hospital information system components are displayed in graph (1) (Hebda., Czar P., Mascara C., 1998).

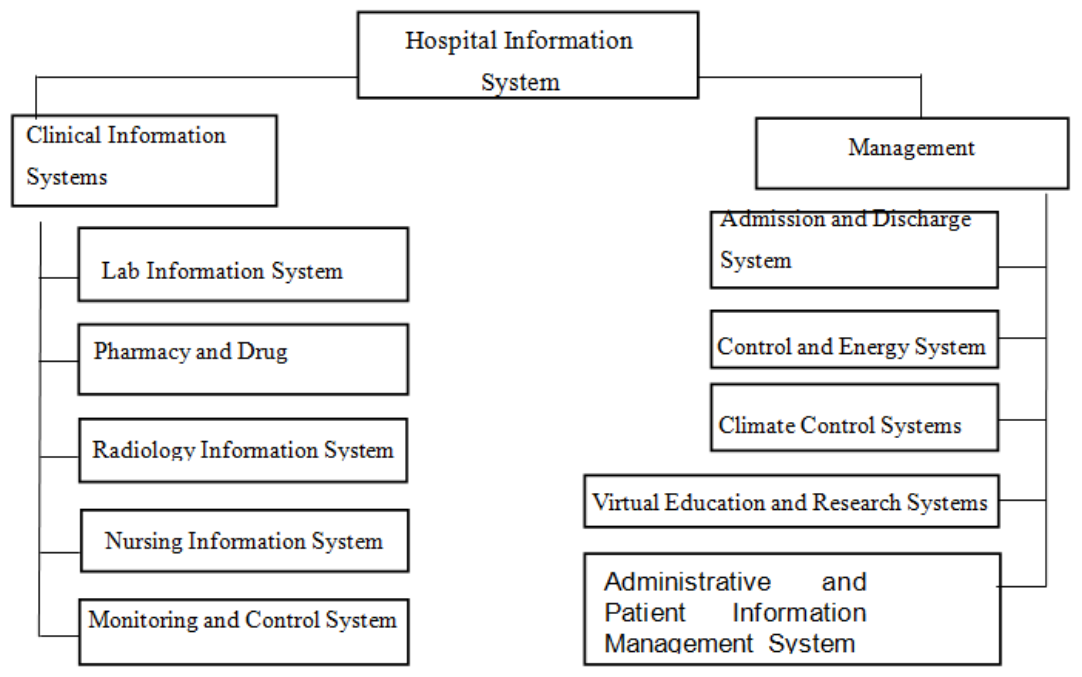

Graph 1. Physical Functional Components of the Hospital Information System

\subsection{Role of the Satisfaction of the Patients, Medical and Educational Staff}

Attachment theory showed that it probably develops when the individual's needs and expectations are met in a place. Therefore, the individual's satisfaction of a place is one of the most important dimensions which should be studied The more the needs and expectations are met in a place, a stronger emotional relationship would develop (Daneshpour, S, 2011,p, 40). In some studies (e.g. Bonaiuto et al, 1999), the factors affecting the place attachment are known as community attachment and place satisfaction. Place attachment theory states that people develop place attachment based on their expectations stemming from their past experience of familiar places and cognitive procedure. Their satisfaction also depends on factors such as facilities, the place accordance with function and context, stability, visual features, management, place economic value, the residents' idea of similar units and the place social texture, city planning and architectural characteristics, social relationships and the place contextual features (Daneshpour, 2011). patient Satisfaction (PS) may be considered to be one of the desired consequences of care, information about PS should be as essential to assessments of quality as to the arrangement and management of health care systems (Andaleeb SS, Siddiqui N, Khandakar S. 2007). Assessing health care quality and improving PS have become increasingly widespread, particularly among health care suppliers and customers of health care due to more knowledgeable customers (Soufi G, Belayachi J, Himmich S, Ahid S, Soufi M, Zekraoui A, et al. 2010). Although it may seem impossible to keep all patients satisfied, we can get a high level of satisfaction on related factors and trying to improve (Soleimanpour H, Gholipouri C, Salarilak S, Raoufi P, Vahidi RG, Rouhi AJ, et al. 2011,p,2). Assessment of health care quality and improving patient's satisfaction has become increasingly prevalent particularly among health care providers and purchasers of health care system (Soufi G, Belayachi J, Himmich S, Ahid S, Soufi M, Zekraoui A, et al. 2010). The highest satisfaction of patients was from speed of admission, courtesy of the physician and nursing skills for performing medical orders, respectively. The lowest satisfaction was from comfort and pleasantness of the waiting area, amount of time spent with doctors and length of waiting time before physicians visit, respectively. As the study by Zohrevandi shows that total score of five assessed sections related to Patients comfort and residential aspects, physicians care, nurse care, behavioral aspects and waiting time for services are on average level but the nurse care aspects have the best level among five sections and waiting for services and behavioral aspects gained the maximum dissatisfaction (Zohrevandi B, Tajik H. 2014,p, 162) Present study showed that the lowest satisfaction of patients was from comfort and pleasantness of the waiting area, amount of time spent with doctors and length of wait before visiting by physicians. Therefore try for reducing waiting time, providing a comfortable environment, increasing the time of visit with emergency physicians and enhance service quality based on patients' needs can reduce the patient dissatisfaction. The hospital environmental health and the patients' safety are two main factors which lead to the satisfaction of the hospital' patients (Sadoughi F,. 2011). The following table by Fair hall shows the factors affecting the patients' safety (Fairhall,K, et al, 2009). 
Table 1. The patients' satisfaction of the clinical centers results from the following

\begin{tabular}{l}
\hline The patients' safety \\
\hline 1- Physical injuries (falling to the ground, exe.) \\
2- Medical errors \\
3- Hospital infections \\
4- Complete well-being and recovery (not just physically) \\
5- Emotional sphere (human dignity, exe.) \\
\hline
\end{tabular}

\subsection{Time}

Duration of the individuals' familiarity with a place, the use period, and the settlement period cause place attachment regardless of other factors (Daneshpour, S, 2011,p, 40).

\subsection{Individual-Place Interaction}

Based on their way of thinking and expectations, individuals have different judgments and feelings towards a place and make different use of it that can be studied in terms of cognitive, emotional and functional interactions (Daneshpour, S, 2011,p, 40).

\subsection{Participation in Design}

Individuals' participation in the construction of a place makes them have a stronger and better feeling about that place which results in place attachment, social relationship development, maintenance of historic roots, relaxation, and safety (Daneshpour, S, 2011,p, 40). Providing participation opportunities is reflective of the individual's place needs and expectations and determines their future life style (Altman, I.1993,p, 60).Marcus has studied place memories through the students' paintings, adults' recalling of childhood places and the elderly's memories of their living place. According to him, people make a feeling of identity inside them based on social relationships, experiences and the surrounding places based on which they build up their desires and wishes. On his study on the children's place attachment, Chawla states that "Since place attachment can affect a child's life quality, it can have a permanent effect on them" (Chawla, L. 1992,p, 63).

3.6 Role of Physical and Functional Spaces on the Psychological, Neurocognitive and Physical Well-Being of the Educational and Medical Staff and the Patient

The role which deals with the satisfaction of the individual goals and needs based on the place ability to meet the users' needs in comparison with other similar places depends on the individual's past experiences, place access and the existing activity models (Daneshpour, S, 2011,p, 40). Some spatial qualities impact the different dimensions of the patients' well-being at therapeutic environments. A summary is presented in table (2) that is specific to hospitals and clinical centers (Heerwagen, J, 2000,p,25).

Table 2.The relationship between the well-being dimensions and the building architectural characteristics

\begin{tabular}{|c|c|c|c|}
\hline Health Dimensions & Physical well-being & Psychological well-being & Neurocognitive well-being \\
\hline \multirow{10}{*}{$\begin{array}{l}\text { The Building } \\
\text { Architectural } \\
\text { Features }\end{array}$} & \multirow{2}{*}{$\begin{array}{l}\text { Cleanliness } \\
\text { maintenance } \\
\text { internal spaces }\end{array}$} & Daylight & Temperature \\
\hline & & Penetration of sunlight & Air conditioning \\
\hline & \multirow{2}{*}{$\begin{array}{l}\text { Operation and } \\
\text { maintenance of } \\
\text { mechanical facilities }\end{array}$} & $\begin{array}{l}\text { Access to delightful views } \\
\text { from the windows }\end{array}$ & $\begin{array}{l}\text { Cleanliness / maintenance of internal } \\
\text { spaces }\end{array}$ \\
\hline & & Relationship with Nature & Selection of materials \\
\hline & \multirow{6}{*}{$\begin{array}{l}\text { Air conditioning } \\
\text { Selection of materials } \\
\text { Temperature } \\
\text { Individual control of } \\
\text { environmental } \\
\text { conditions }\end{array}$} & Non-crowdedness & $\begin{array}{l}\text { Individual control of environmental } \\
\text { conditions }\end{array}$ \\
\hline & & Individual control of & Proper lighting \\
\hline & & environmental conditions & Not-dazzlingly of lights and windows \\
\hline & & Safety & $\begin{array}{l}\text { Access to delightful views from the } \\
\text { windows }\end{array}$ \\
\hline & & & Appropriate visual \\
\hline & & & Relationship with Nature \\
\hline
\end{tabular}




\section{Conclusion}

As definition suggest, place attachment refers to the individuals' emotional relationship with a place that has different levels rooted in the individual's past characteristics and experiences (Attachment Theory) and also the individual's needs and expectations of a place and the place capacity to meet the needs and expectations. Therefore, place attachment develops when a place can meet the needs and expectations of an individual. In fact, different place attachment aspects make the place image. As stated in the Attachment Theory and Proshansky's viewpoints on identification with a place, to encounter the surrounding phenomena such as the place, the main human tool is the individual who interferes consciously or unconsciously which includes the following three areas: beliefs, thoughts and perceptions of the individual about a place and similar places based on past experiences which make the individual's judgment of a place during the cognitive interaction. The individual's preferences and feelings about a place during emotional interaction make the place assessment through emotional interaction with a place. In fact, based on the afore-mentioned results, it can be stated that in place attachment process, two elements of human and place enter a process through a third element of individual-place interaction cognitively, emotionally, and functionally. Time should also be discussed as the fourth element. If we look at the obtained results and also the individual-place subject from a designer's point of view, participation and satisfaction of the patients, medical and educational staff can also be added to the previous elements. Therefore, if designers mean to enhance place attachment in various hospital spaces, they should take these six elements into consideration. A graph (2) displaying place attachment in hospital spaces follows. Future researches can conduct survey study in hospitals to discover other dimensions of place attachment.

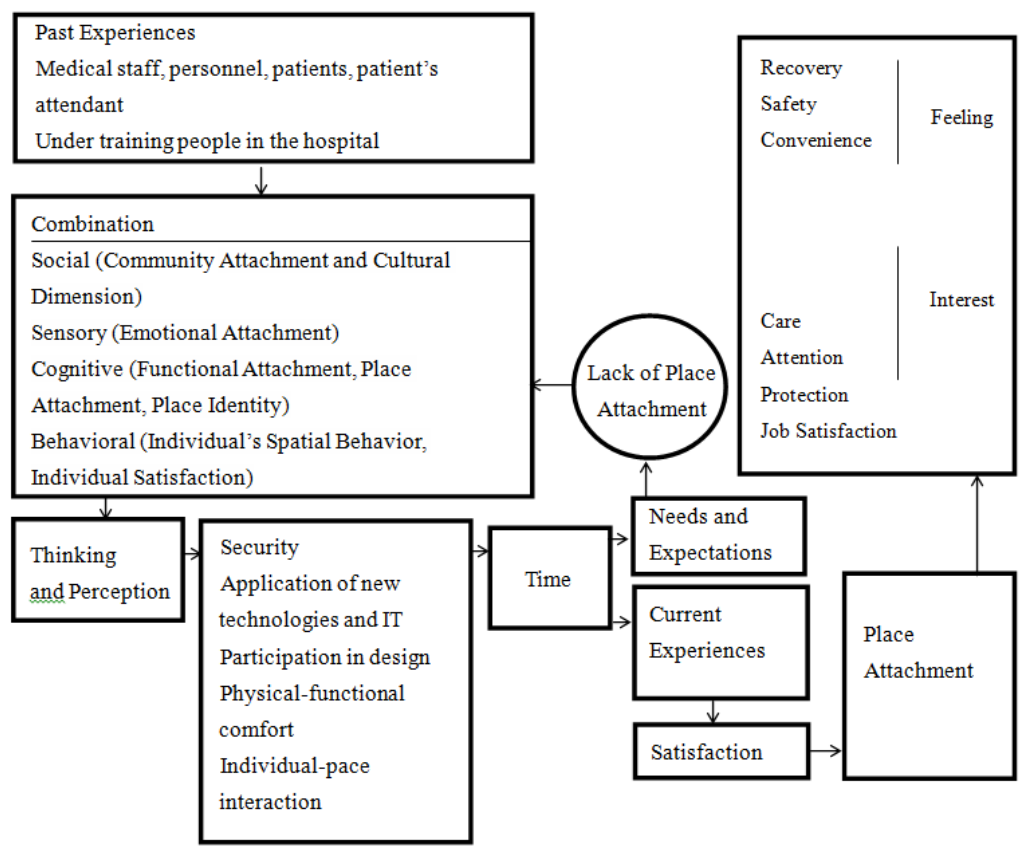

Graph 2. Place attachment procedure model in hospital (Source: Authors)

\section{References}

Altman, I. (1993). Dialectics, physical environments and personal relationships. Communication Monographs, 60, 26-34.

Andaleeb, S. S., Siddiqui, N., \& Khandakar. S. (2007). Patient satisfaction with health services in Bangladesh. Health Policy and Planning, 22(4), 263-73. Exploratory study of whitewater recreationists, Leisure Sciences, 22, 233-257.

Bonaiuto, M, et al. (1999). Multidimensional Environment quality and neighborhood attachmen. Urban Environment, 19, $331-352$

Bonaiuto, M., Fornara, F., \& Bonnes, M. (2002). Indexes of perceived residential environment quality and 
neighborhood attachment in urban environments: A confirmation study on the city of Rome. Landscape and Urban Planning, 988, 1-12.

Bricker, K. S., \& Kerstetter, D. L. (2000). Level of specialization and place attachment: An............

Brown, B., \& Perkins, D. (1992). Disruption in place attachment. In I. Altman, \& S. Low (Eds.), Place attachment (pp. 119e132). New York: Plenum

Chavis, D. M., \& Pretty, G. (1999). Sense of community: Advances in measurement and application. Journal of Community Psychology, 27(6), 635-642.

Chawla, L, (1992). Childhood place attachments. In I. Altman, \& S. Low (Eds.), Place Attachment, New York. Plenum Press, 63-86.

Daneshpour, S. (2011). Place Attachment And investigation of its effective factors, Honar-ha-ye-Ziba-Memari-Va-Shahrsazi. Spring, 1(38), 40-44.

Easthope, H. (2004). A place called home. Housing. Theory and Society, 21(3), 128-138.

Eisenhauer, B. W., Krannich, R. S., \& Blahna, D. J. (2000). Attachments to special places on public lands: An analysis of activities, reason for attachments, and community connections. Society and Natural Resources, $13,421-441$.

Evans, G. W., Kantrowitz, E., \& Eshelman, P. (2002). Housing quality and psychological well-being among the elderly population. Journal of Gerontology, 57b(4), 381-383.

Fairhall, K, et al. (2009). Single, bed versus multi-bed hospital: the case for patient safety world, Health Design Journal, October, 9-57

Goldberg, S. (2000). Attachment theory Social developmental, and clinical perspectives. Analytic press, inc, 85.

Harris, P. B., Werner, C. M., Brown, B. B., \& Ingebritsen, D. (1995). Relocation and privacy regulation, a cross-cultural analysis. Journal of Environmental Psychology, 15(4), 311-320.

Hebda., Czar P., \& Mascara C., (1998), Handbook of information for nurses and health care professionals, Addison Wesley Longman,(Menlo Park, Calif), California, USA

Heerwagen, J. (2000). Do green buildings enhance the wellbeing of workers Environmental. Design \& Construction, 25-26.

Hern_andez, B., Hidalgo, M. C., Salazar-Laplace, E., \& Hess, S. (2007). Place attachmentand place identity in natives and non-natives. Journal of Environmental Psychology, 27(4), 310-319.

Hidalgo, M. C., \& Hern_andez, B. (2001). Place attachment conceptual and empirical questions. Journal of Environmental Psychology, 21, 273-281.

Hummon, D. (1992). Community attachment. Local sentiment and sense of place. In I. Altman, \& S. M. Low (Eds.), Place attachment (pp. 253-277). New York and London: Plenum.

Kaltenborn, B. P. (1998). Effects of sense of place on responses to environmental impacts. Applied Geography, 18(2), 169-189.

Kaplan, S., \& Kaplan, R. (1984). Cognition and environment. New York: Praeger.

Kyle, G. T., Absher, J. D., \& Graefe, A. R. (2003). The moderating role of place attachment on the relationship between attitude toward fees and spending preferences. Leisure Sciences, 25, 33-50.

Kyle, G., Graefe, A., Manning, R., \& Bacon, J. (2004). Effects of place attachment on users perceptions of social and environmental conditions in a natural setting. Journal of Environmental Psychology, 24, 213-225.

Lewicka, M. (2011). On the varieties of people's relationships with places. Hummon's typology revisited. Environment and Behavior, 43(5), 676-709.

Lewicka, M. (2011). Place attachment. How far have we come in the last 40 years? Journal of Environmental Psychology, 31(3), 207-230.

Low, S. M., \& McDonogh, G. W. (2001). remapping the city: Place, Order and Ideology. American Anthropologist, 103(1), 5-6.

Low, S. M., \& Altman, I. (1992). Place attachment: a conceptual inquiry. In Low, S. M., \& Altman, I. (Eds.), Place Attachment, New York. Plenum Press, 12, 1-12

Mesch, G. S., \& Manor, O. (1998). Social ties, environmental perception, and local attachment. Environment and 
Behavior, 30, 504-519.

Milligan, M. J. (1998). Interactional past and potential: the social construction of place attachment. Symbolic Interaction, 21(1), 1-33.

Morgan, P. (2010). Towards a developmental theory of place attachment. Journal of Environmental Psychology, $30(1), 11 \mathrm{e} 22$.

Pretty, G., Chipuer, H. M., \& Bramston, P. (2003). Sense of place among adolescence and adults in two rural Australian towns: The discriminating features of place attachment, sense of community and place dependence in relation to place identity. Journal of Environmental Psychology, 23, 273-287.

Proshansky, H. M. (1978). The City and Self-Identity. Environment and Behavior, 155, 147-169.

Proshansky, H. M., Fabian, A. K., \& Kaminoff, R. (1983). Place identity, physical world socialization of the self. Journal of Environmental Psychology, 3(1), 57e83.

Proshansky, H. M., Fabian, A. K., \& Kaminoff, R. (1983). Place-identity: physical world socialization of the self, Journal of Environmental Psychology, 3, 57-83.

Rollero, C., \& De Piccoli, N. (2010). Does place attachment affect social well-being? Revue Europ_eenne de Psychologie Appliqu_ee, 60(4), 233-238.

Rosenberg, M. J., \& Hovland, C. I. (1960). Cognitive, affective, and behavioral components of attitudes, New Haven. Yale University Press, 1-14.

Rubinstein, R. L., \& Parmelee, P. A. (1992). Attachment to place and representation of the life course by the elderly, New York. Plenum Press, 139.

Sadoughi F,. (2011), Patient Safety Information System: Purpose, Structure and Functions. Mazand University Medical Science, 21(85), 174-188.

Scherl, L. M. (1989). Self in wilderness: Understanding the psychological benefits of individual-wilderness interaction through self-control. Leisure Sciences, 11, 123-135.

Shamai, S. (1991). Sense of place and empirical measurement. Geoforum, 22(3), 347-358.

Soleimanpour, H., Gholipouri, C., Salarilak, S., Raoufi, P., Vahidi, R. G., \& Rouhi, A. J., et al. (2011). Emergency department patient satisfaction survey in Imam Reza Hospital, Tabriz, Iran. International Journal of Emergency Medicine, 4, 2.

Soufi, G., Belayachi, J., Himmich, S., Ahid, S., Soufi, M., \& Zekraoui, A., et al. (2010). Patient satisfaction in an acute medicine department in Morocco. BMC Health Services Research, 10, 149.

Stedman, R. C. (2003). Is it really a social construction? The contribution of physical environment to Sense of place. Society and Natural Resources, 682, 671-685.

Stedman, R. C. (2003). Is it really just a social construction? The contribution of the physical environment to sense of place. Society\&NaturalResources, 16(8),671e685.

Stokols, D., \& Shumaker, S. A. (1981). People in places: A transactional view of settings, Erlbaum, 41-488.

Tuan, Y. F. (1977). Space and place. The perspective of experience. Minneapolis: University of Minneapolis Press.

Tuan, Y. F. (1980). Rootedness versus sense of place. Landscape, 24, 3-8.

Twigger-Ross, C., Bonaiuto, M., \& Breakwell, G. (2003). Identity theories and environmental psychology. In M. Bonnes, T. Lee, \& M. Bonainto (Eds.), Psychological theories for environmental issues (pp. 203e234). Aedershot: Ashgate.

Van schalk, L. (2008). Spatial intelligence,new futures for architecture: New Futures for Architecture. Johan wiley \&sons Ltd, 9.

Vaske, J. J., \& Kobrin, K. C. (2001). Place attachment and environmentally responsible behavior. The Journal of Environmental Education, 18, 16-21.

Warzecha, C. A., \& Lime, D. W. (2001). Place attachment in Canyon lands National Park: Visitors assessment of setting attributes on the Colorado and Green Rivers. Journal of Park and Recreation Administration, 32, 59-78.

Williams, D. R., \& Roggenbuck, J. W. (1989). Measuring place attachment: Some preliminary results. In L. H. 
McAvoy, \& D. Howard (Eds.), Leisure Research Symposium, National Recreation and Park Association, Arlington, 32.

Williams, D. R., \& Vaske, J. J. (2003). The measurement of place attachment: Validity and generalizability of a psychometric approach. Forest Science, 49(6), 830-840.

Wright, P. A., \& Kloos, B. (2007). Housing environment and mental health outcomes. Alevels of analysis perspective. Journal of Environmental Psychology, 27(1), 79-89.

Zohrevandi, B., \& Tajik. H. (2014). A Survey of Patients' Satisfaction in Emergency Department of Rasht Poursina Hospital. Emergency, 2(4), 162-5.

\section{Copyrights}

Copyright for this article is retained by the author(s), with first publication rights granted to the journal.

This is an open-access article distributed under the terms and conditions of the Creative Commons Attribution license (http://creativecommons.org/licenses/by/3.0/). 